\title{
EVALUATION OF SOME CUCURBITACEOUS ROOTSTOCKS 2-EFFECT OF CUCUMBER GRAFTING USING SOME ROOTSTOCKS ON GROWTH, YIELD AND ITS RELATION WITH ROOT-KNOT NEMATODE MELOIDOGYNE INCOGNITA AND FUSARIUM WILT, INFECTION
}

\author{
ABD EL-WANIS, MONA M. ${ }^{1}$, A.W. AMIN ${ }^{2}$ and \\ TOMADER G. ABDEL RAHMAN ${ }^{3}$ \\ 1. Protected cultivation Dept. Horticulture Research Institute ARC, Giaza \\ 2. Cairo University, Faculty of Agriculture, Zoology \& Nematology Dept. \\ 3. Plant pathology Research Institute, ARC, Giaza
}

(Manuscript received 22 October 2012)

\begin{abstract}
Grafting onto specific rootstocks provides resistance to soil borne disease and nematodes. Fusarium wilt disease caused by Fusarium oxysporum (FO) as well as root-knot nematode caused by Meloidogyne incognita (RKN) are the most serious soil pathogens in cucumber soil in open fields and under plastic houses. The present study aimed at selecting four cucurbit rootstocks for their resistance and / or susceptibility to fusarium wilt fungus (FO) and root-knot nematode (RKN) in two successive years (2010 and 2011) in $10 \mathrm{~cm}$-diam. pots under screen house and in naturally infested soil under plastic house conditions. These selective cucurbit rootstocks were Bottle gourd (Lagenaria sicenaria) and Winter squash ( Cucurbita maxima)in autumn season and Wax melon (Benincasa hispida) and Ercola,(C.maximax C.moshata) as hybrid 6001 in spring season. Cucumber scion was Hesham F1 hybrid and Sinai were grafted onto rootstocks in autumn and spring seasons respectively Results indicate that in autumn and spring seasons, the cucumber plants grafted onto Bottle gourd, Lagenaria sicenaria, Winter squash, Cucurbita maxima, Wax melon, Benincasa hispida and C.maxima $\times$ C.moshata Ercole hybrid F1 No. 6001 rootstocks grown in pots had highly significantly less root galling, number of females and egg-masses than non-grafted cucumber. Data generally indicated that, Cucurbita maxima were highly resistant and resistant to $M$. incognita in soil infested with nematode only and or fungus, respectively. Lagenaria sicenaria was moderately resistant to root-knot nematode in both cases. On the other hand, cucumber seedlings grafted onto rootstocks, Lagenaria sicenaria or Cucurbita maxima grown in pots were highly resistant to (RKN) in soil infested with nematode only and or fungus (FO). Non-grafted cucumber seedlings var. Hesham and Sinai were rated as susceptible and highly susceptible to nematode infection in autumn and spring seasons respectively. In spring season, Benincasa hispida and C.maxima $\times$ C.moshata Ercole hybrid F1 No. 6001 were moderately resistant (MR) to infection by $M$. incognita when soil inoculated by nematode only and or Fusarium oxysporum in pot experiment. In autumn season, grafted and non-grafted plants were rated as resistant (R) and highly resistant (HR) to wilt fungus, Fusarium oxysporum (FO) in soil infested with fusarium wilt (FO) only and /or nematode (RKN). Cucumber scion, Cucumis sativus var. Hesham F1 hybrid which rated as susceptible (S) and
\end{abstract}



YIELD AND ITS RELATION WITH ROOT-KNOT NEMATODE

MELOIDOGYNE INCOGNITA AND FUSARIUM WILT, INFECTION

highly susceptible (HS) in pots inoculated by wilt fungus (FO) only and/ or RKN, respectively. Also, in spring, all grafted and nongrafted plants were rated as highly resistant (HR) to wilt fungus, Fusarium oxysporum (FO) compared to cucumber scion, Cucumis sativus var. Sinai hybrid which rated as highly susceptible (HS) in pots in both cases inoculated by wilt fungus (FO) only and /or nematode (RKN). Data indicated also that both pathogens significantly decreased the plant criteria (Shoot and root weight, and shoot and root length), when they were inoculated by RKN or / and fusarium fungus (FO) compared to un-inoculated control. Also, the inoculation with root-knot nematode (RKN) alone decreased the plant criteria than inoculation with Fusarium and nematodes. In natural infested soil experiments in both seasons, data was completely similar the data recorded in pots. Plant shoot growth characteristics; cucumber yields (no of fruits per plant and total fruits per plant and yield in one meter square), Cucumber fruit characteristics, and chlorophyll contents were significantly improved in plant leaves compared with scion cucumber. Consequently, the shoot macro-elements were increased compared with scion cucumber.

Keyword: Cucumber, Cucurbit rootstocks, Fusarium wilt, Root-knot nematode, grafting.

\section{INTRODUCTION}

Grafting onto specific rootstocks, generally, provides resistance to soil borne diseases and nematodes and increases yield (Cao et al., 2005). It's an effective technology for use in combination with more sustainable crop production practices, including reduced rates and overall use of soil fumigants in many countries (Kobayashi 2005; Kubota et al., 2008). In the 1990s, nearly $60 \%$ of open fields and greenhouses in Japan and $81 \%$ in Korea (Lee, 1994) producing muskmelon, watermelon, cucumber, tomato and eggplant were reportedly planted with grafting. Grafting may be a valuable tool for vegetable growers to cope with pest management challenges in production of cucurbits and solanaceous crops (Charles et al., 2012; Davis, 2010; Sigüenza et. al., 2005). Today, over 500 million grafted seedlings are produced annually in Japan (Kobayashi, 2005).

Cucumber, Cucumis sativus $\mathrm{L}$. is one of the most important vegetable crops growing in Egypt and many countries. It's grown in Egypt in open fields as a summer crop and under plastic houses during winter season in more than 32,755 plastic houses with total yield of about 109,920 tons/year (Anonymous, 2012). As for vegetable crops production in greenhouses, soil-borne diseases and nematodes cause most of the damage from intensive and continuous cropping (Oda 1999 and 2002). Cucumber crop suffers from several infections by serious fungal diseases and nematodes. The most prevalent and damaging soil borne pathogens were resulting in 
severe yield quality and quantity losses in plants. Southern root-knot nematode, Meloidogyne incognita (RKN) and fusarium wilt fungus, Fusarium oxysporum (FO) are the most serious soil borne diseases in cucumber Rhizosphere (Sharma et al., 1995).

There are several ways to control the nematodes and fusarium wilt, none of them proved to be more effective. No commercial cultivars or hybrids of cucumber are recorded as resistant to root knot nematode. Therefore, the possible approach to overcome such disease is using grafting on resistant wild or domesticated cucurbitaceous rootstocks as an active, safe and clean method. Grafting onto resistant rootstocks of wild or domesticated species of cucurbit plants is the most known means to protect the scion from the attack by these pathogens. Grafting has been used to control soil borne pathogens in vegetables since 1920 in Japan and Korea, where land use is very limited (Ashita, 1927; Lee, 1994; Sakata et al., 2008). After the first trail, the cultivated area of grafted vegetables, as well as the kinds of vegetables being grafted has been consistently increased. The highest number of grafted plants was in watermelon followed by tomato, eggplant, melon and cucumber.

This work was planned to study and evaluate cucumber scion plants grafted onto four selected cucurbitaceous plants resistant against root-knot nematode and fusarium wilt disease in two successive years in four seasons (2009-2011) in pots (artificial infection) under screen house and in natural infested soil under plastic house conditions and effect of grafting on growth and yield.

\section{MATERIALS AND METHODS}

This experiment was carried out in the inspected fields and greenhouses located at Kaha Research Station, Horticultural Research Institute (H.R.I.), Agricultural Research Center in qualiobyia governorate.DiseasedCucumber plants showing the typical symptoms of wilt and/ or galls of root-knot nematodes were collected during 2008- 2009. The plants (samples) were uprooted and preserved in plastic bags which were kept in an icebox during transportation to laboratory. Then samples were kept in a refrigerator at $5{ }^{\circ} \mathrm{C}$ for mass rearing procedures. The fungus was isolated on potato dextrose agar (PDA) medium. The inoculums used in the foregoing mass rearing are consisted of uniform $4 \mathrm{~mm}$. diam. agar discs bearing 7 days old growth of the desired fungus under aseptic conditions. The inoculums were grown in $500 \mathrm{ml}$. milk bottles containing the following sterilized substrate per bottle $(75 \mathrm{~g}$. washed and dried maize, $100 \mathrm{~g}$ washed dried coarse sand and $65 \mathrm{ml}$ tap water). The bottles were autoclaved before being incubated at $25{ }^{\circ} \mathrm{C}$ for two weeks to obtain sufficient growth of the fungus. The inoculums were, then, thoroughly mixed with sterilized soil at the desired 
rate and time as follows: Five grammes per kilogram were used for both sterilized growing medium. Root-knot nematode, Meloidgyne incognita was extracted and identified by Taylor and Sasser (1978) under stereo - microscope by perennial pattern technique and mass rearing procedure on eggplant seedlings till inoculation time.

\section{1- Screen house experiments.}

Twelve cucurbit rootstocks were evaluated in 2009 in pots infested by the southern root-knot nematode, Meloidogyne incognita (RKN) and/ or Fusarium oxysporum in screen house in College of Agriculture, Cairo university, only four rootstocks were selected as resistant to nematode (RKN) and fungus wilt (FO) diseases as reported by (Amin, et al., 2013). Commercial Cucumber scion, Cucumis sativus var. Hesham F1 hybrid was grafted onto Bottle gourd, Lagenaria sicenaria and Winter squash, Cucurbita maxima as rootstocks in autumn seasons (2009 and 2010). Also, commercial cucumber scion, Cucumis sativus, Sinai hybrid was grafted onto Wax melon, Benincasa hispida and C.maximax C.moshata Ercola hybrid F1No.6001 as rootstocks in spring seasons (2010 and 2011). Also, two experiments were recorded in autumn and spring seasons (2009-2011) and on four rootstocks in plots as semi-field conditions naturally infested by soil borne disease in autumn and spring seasons under plastic house.

Four selected resistant cucurbitaceous rootstock seeds were selected and grown in pot experiments. Bottle gourd, Lagenaria sicenaria and winter squash, Cucurbita maxima were grown in autumn season, and other two rootstocks wax melon, Benincasa hispida and C.maxima $\times$ C.moshata Ercole hybrid F1 No. 6001 were grown in spring season. Cucumber scions Hesham F1 hybrid from Royal\&sluis Co. and Sinai hybrid from (H.R.I.) were sown in 84-cells tray as control in $1^{\text {st }}$ August (autumn) and $15^{\text {th }}$ Feb. (spring), respectively. Each seed of the rootstock was sown in 84-cell tray for 7-8 days earlier than cucumber seeds of the scion in autumn season and for 10-11 days earlier in spring season. Rootstock seedlings transplanted to $10 \mathrm{~cm}-\mathrm{d}$ plastic pots filled with $1 \mathrm{~kg}$ sterilized sandy-loam soil $(1: 1 \mathrm{v} / \mathrm{v})$ free of plant pathogen and nematode after germination and appearance of the first true leaf of rootstock seedlings and scions. Seedlings of rootstocks and scions were ready for grafting at the appearance of the second true leaf of rootstocks. Seedling of Rootstocks were picked between the two cotyledons after removing the top (leaves) by razor, scion were prepared by cutting the seedling below the two cotyledons with a distance of $2-3 \mathrm{~cm}$ with a basal end in the form of a wedge. Wedges were inserted in the picked part of the stocks on condition that the cotyledons of the Rootstocks and scion were held with grafting clips (Oda, 1999). The seedlings were placed under plastic tunnel at optimum temperature and humidity. The compatibility was determined after 7 days at 
relatively high temperature $\left(25-30{ }^{\circ} \mathrm{C}\right)$ in autumn seasons and 10 days at relatively low temperature $\left(20-25{ }^{\circ} \mathrm{C}\right)$ in spring season from conducting after grafting stage (following the new growth on the scions). The plastic tunnel was, gradually, opened for adaptation. There were five replicates for each treatment (5 pots). They were arranged in a completely randomized design in screen house. The pots were watered daily. The pots were divided into four groups. The first group was inoculated with 500 infective stages of root-knot nematode (RKN), Meloidogyne incognita only (obtained from rearing mass on eggplant roots) in five holes around the seedling roots and the second group received 500 infective stages of nematodes (RKN) and 5\% Fusarium oxysporum infested soil around the seedling roots, the third group received 5\% infested soil by Fusarium oxysporum only and the fourth group served as control plants (added un-inoculated growing medium). After nine weeks of nematodes and fungus inoculations, roots of plants were, carefully, uprooted and nematodes in soil and roots were counted and recorded as root galls and egg-masses index according to Taylor and Sasser (1978). Disease incidence caused by Fusarium oxysporum during the growth period was recorded according to Kesevan and Chounhury, (1977). The number of galls, females and egg-masses and reproductive factor (RF) as compared to untreated pots were calculated for root-knot nematode (RKN). Length and weight of shoots and roots were recorded at the end of autumn and spring. The aforementioned characters were investigated in the presence of nematodes and/or wilt fungus disease compared to control plants. Another half number of pots received un-inoculated growth media prepared by grafted transplanting seedlings in the screen house. The pots under screen house were irrigated daily and fertilized according to the Egyptian Ministry of Agriculture recommendations. The experiment was repeated two times during autumn 2010 and spring 2011 successive seasons. Data was statistically analyzed using new least significant Difference (New LSD). (Waller \& Duncan, 1969).

\section{2- Field experiments under plastic house conditions.}

Four experiments were carried out in naturally infested soil by root-knot nematode, M.incognita and wilt fungus disease. In two successive autumn seasons 2009-2010, cucumber var. Hesham was grafted onto Bottle gourd, Lagenaria sicenaria and winter squash, Cucurbita maxima. In two successive spring seasons (2010-2011), cucumber var. Sinai was grafted onto wax melon, Benincasa hispida and C.maxima $x$ C.moshata Ercole hybrid F1 No. 6001 under plastic house (40 m. Long x 9 m. width $x$ 3m. height) at Kaha Research Station, Horticulture Res. Inst., Agric Res. Center, Ministry of Agriculture. The soil texture of the experimental field was loamy clay. The plants under plastic tunnels were irrigated by drip irrigation and fertilized according to 
the recommendations of the Ministry of Agriculture. The treatments were arranged in a completely randomized block design with three replicates. Each experimental plot consisted of three treatments. Each treatment was layered in one ridge, $40 \mathrm{~m}$. long and $1 \mathrm{~m}$. width. Seedlings were planted on the two sides of each ridge at $50 \mathrm{~cm}$ apart. 10 plants were randomly chosen from each experimental plot at 60 days-old after sowing. Plant height, number of leave/plant, leaf area and chlorophyll contents (spade) were recorded. Plant shoot characteristics, fruit characteristics, yields of cucumber per plant and per one square meter, physical characteristics of fruits and $\mathrm{N}$, $\mathrm{P}, \mathrm{K} ., \mathrm{Mg}$ and $\mathrm{Ca}$ contents of plant shoot were analyzed using the modified micro kjeldahl method as described by Plummer (1971). The number of galls, females and egg-masses and reproductive factor (RF) in plots were calculated for root-knot nematode (RKN). Length and weight of shoots and roots were recorded at the end of autumn and spring. The yield quality and quantity were recorded per plant and per one meter square. N, P, K, Ca and Mg macro-elements contents were analyzed in shoot system. The aforementioned characters were investigated in the presence of nematodes and /or wilt fungus diseases compared to control plants. Data were statistically analyzed using New LSD as the method of Waller and Duncan( 1969).

\section{RESULTS AND DISCUSSION}

In pot experiments, in autumn, cucumber grafted onto Bottle gourd, Lagenaria sicenaria and Winter squash, Cucurbita maxima rootstocks, had highly significant less root galling, number of females and egg-masses than non-grafted cucumber (Table 1). In addition, data presented in (Table 1 ) indicate that the cucurbit rootstocks varied in their rates of resistance and susceptibility according to Hemeng (1989). It was found that cucumber scion grafted onto, Lagenaria sicenaria and Squash, Cucurbita maxima were moderately resistant (MR) to root-knot nematode (RKN) when the pots received either root-knot nematode and / or wilt fungus (FO). While, non-grafted, Lagenaria sicenaria was rated as susceptible (S) to root-knot nematode (RKN). Squash, Cucurbita maxima was rated as highly resistant (HR) and resistant (R) to root-knot nematode (RKN) when the pots received either root-knot nematode and/or wilt fungus disease, respectively. While, non-grafted Winter squash, Cucurbita maxima was rated as resistant $(R)$ and susceptible (S) when the pots received either root-knot nematode only/and wilt fungus (FO), respectively compared with highly susceptible (HS) cucumber scion, Cucumis sativus var. Hesham F1 hybrid. All grafted and nongrafted plants were rated as resistant $(R)$ and highly resistant $(H R)$ to wilt fungus, Fusarium oxysporum (FO) according to Kesevan and Chounhury, (1977) index (Table 
1). Cucumber scion, Cucumis sativus var. Hesham F1 hybrid which rated as susceptible (S) and highly susceptible (HS) in pots inoculated by fusarium wilt fungus (FO) and/or root-knot nematode (RKN) respectively (Table 1 ).

In spring, 2010 and 2011, respectively, Cucumber scions var. Sinai F1 grafted onto wax melon, Benincasa hispida and C.maxima $\times$ C.moshata Ercole hybrid F1 No. 6001 rootstocks had highly significant less number of galls, females and egg-masses than non-grafted cucumber var. Sinai F1(Table 3 ). Data also indicated that, grafting onto Benincasa hispida was rated as susceptible (S) and moderately resistant (MR) when the pots received either root-knot nematode and/ or fusarium wilt fungus (FO), respectively. While, non-grafted ones were rated as susceptible in both cases. C.maxima $\times$ C.moshata Ercole hybrid F1 No. 6001 was rated as moderately resistant (MR) when the pots received either root-knot nematode (RKN) and/ or wilt fungus (FO). All grafted and non-grafted plants were rated as highly resistant (HR) to wilt fungus, Fusarium oxysporum (FO) compared to cucumber scion, Cucumis sativus Sinai hybrid which rated as highly susceptible (HS) in pots inoculated by fusarium wilt fungus (FO) and or root-knot nematode (RKN) (Table 3). In spite of certain rootstocks recorded as susceptible to root-knot nematode (RKN) but the population of females and egg-masses were highly significant less than control.

As for plant criteria, shoot and root weights, and shoot and root lengths, It is clear that both pathogens significantly $(P \leq 0.05)$ decreased the plant criteria when they inoculated alone or together compared to un-inoculated control (Tables 2 and 4). Also, the inoculation with root-knot nematode (RKN) alone decreased the plant criteria more than inoculation with both pathogens. The primary purpose of grafting vegetables worldwide has been to provide resistance to soil borne diseases (Oda, 1994).

In greenhouse experiments, of naturally infested soil in both seasons, data were completely similar to data recorded in pots in autumn and spring seasons (Tables 5-14). It was noticed that in autumn and spring, cucumber grafted onto Bottle gourd, Lagenaria sicenaria and Winter squash, Cucurbita maxima rootstocks in autumn seasons and Wax melon, Benincasa hispida and C.maxima $\times$ C.moshata Ercole hybrid F1 No. 6001 had highly significant less number root of galls, females and egg-masses less than non-grafted cucumber (Tables 5 and 6). Also, plant criteria, as shoot growth characteristics, cucumber yields (No. of fruits/plant and total fruits per square meter), cucumber fruit characteristics, and chlorophyll contents (spade) were highly significant improved compared with scion cucumber (Tables 7 and 14). Consequently, the shoot macro-elements were increased compare with scion cucumber (Tables 10 and 14). Also, the chlorophyll contents on grafted rootstocks 
was increased between 7.9-15.9\% and $0.54-0.8 \%$ more than non-grafted cucumber in autumn 2009 and 2010; respectively (Table 7). While, the chlorophyll contents on Wax melon, Benincasa hispida and C.maxima $\times$ C.moshata Ercole hybrid F1 No. 6001 were increased between $4.8-1.6 \%$ and $16.1-2.0 \%$ more than non-grafted cucumber in spring 2010 and 2011; respectively (Table 11). The total yields $/ \mathrm{m}^{2}$ were highly significantly increased on grafted Bottle gourd, Lagenaria sicenaria and Winter squash, Cucurbita maxima rootstocks in 2009-2010 autumn seasons $24.1-8.7 \%, 39.6$ $21.1 \%$;respectively compare with non-grafted cucumber (Table 8). On the other hand, the total yields $/ \mathrm{m}^{2}$ were highly significantly yield increased on grafted Bottle gourd, Lagenaria sicenaria and winter squash, Cucurbita maxima rootstocks in autumn seasons (2009-2010) $24.1-8.7 \%$; $39.6-21.1 \%$. ; Respectively. While, the total yields $/ \mathrm{m}^{2}$ were highly significantly yield increased on grafted Wax melon, Benincasa hispida and C.maxima $\times$ C.moshata Ercole hybrid F1 No. 6001 spring seasons (2010-2011) $25.7-57.1 \%$ and $54.5-60.6 \%$; respectively compared with non-grafted cucumber (Table 12).

From the present data, It is clear that grafting onto rootstocks are significantly decreased the population of root-knot nematode and fungus disease year by year. The level of both populations will be under management. These results agreed with Charles, et al. (2012) who showed that under severe RKN pressure, grafting may be an economically feasible pest control measure to help maintain a profitable production giving that the risk of economic crop losses due to RKN outweighed the higher cost of grafted transplants. Also, King et al. (2008) found that the potential loss of methyl bromide as a soil fumigant combined with pathogen resistance to commonly used pesticides will make resistance to soil borne pathogens more important in the future. The increment in plant criteria may be due to reduction in nematode and fungus population and improvement photosynthesis and carbohydrate metabolism (Tables 7-14). Results of Yi-Fei, et. al. (2011) indicated that grafting helps improve photosynthesis and carbohydrate metabolism in leaves of muskmelon, Cucumis melo L.. They also explain the increment in grafted cucumber plant criteria, that grafting rootstocks increased chlorophyll $a+b$ content and the leaf area in middle and late developmental stages of the plant. These results agreed with our results in Tables 7 to Table 14 indicated that improvement in plant growth, yield quantity and quality, increment in chlorophyll contents, increments in leaf area and macro-elements in plant shoots. For these reasons, the use of grafted cucumber on resistant rootstocks as a means of managing nematode populations (RKN) and fusarium wilt (FO) soil borne in greenhouses must be recommended. Rotation of resistant cucumber has been already proved success for reducing $M$. incognita 
infestations in pots under screen house and under greenhouse conditions. These results agree with those recorded in Greece on tomato infested by M. javanica (Tzortzakakis et al., 2000). Herbaceous grafting has been practiced for many years in countries in Asia, Europe, the Middle East, Northern Africa, and Central America. Now, it has been introduced as a relatively new technology in Egypt. As a result of its benefits and values, demand for high-quality grafted seedlings by growers and interest by propagators are expected to be rapidly increased. Kubota et al., (2008) suggested that researchers, extension specialists, and industries need to work together to integrate this modernized technology as an effective tool. Grafting technology in vegetable crops is important because it is associated with intensive cultivation, improving yield quantity and quality, reducing rate and overall use of soil fumigants and pesticides and organic cultivation products (Giannakou \& Karpouzas, 2003, Kacjan \& Osvald, 2004).Year after year, the population of soil borne are successfully decreased.

Kubota et.al., (2008) suggested that one critical item necessary for successful grafted seedling production is uniformity of seedlings used for scion and rootstock. One way to improve the uniformity is the use of automatic sorting machines equipped with a machine vision system as successful means used in many countries. 
Table 1. Evaluation of grafted and non-grafted cucurbit rootstocks infected by Meloidogyne incognita and/or Fusarium oxysporum on nematode population and Fusarium disease index in autumn season in pots under screen house experiment.

\begin{tabular}{|c|c|c|c|c|c|c|c|c|c|}
\hline \multirow{2}{*}{$\begin{array}{c}\text { Treatment } \\
\text { Scion /grafted plant }\end{array}$} & \multicolumn{5}{|c|}{ Number of Nematodes } & \multirow{2}{*}{ 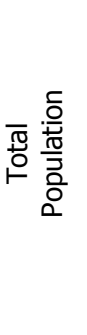 } & \multirow{2}{*}{ GI/EI * } & \multicolumn{2}{|c|}{$\begin{array}{l}\text { Fusarium Wilt } \\
* *\end{array}$} \\
\hline & $\begin{array}{l}\overline{\overline{0}} \\
\dot{n} \\
\dot{\Xi}\end{array}$ & 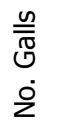 & 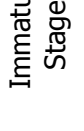 & 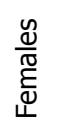 & 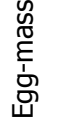 & & & 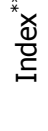 & 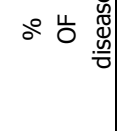 \\
\hline $\begin{array}{l}\text { Cucumis sativus/Lageraria } \\
\text { sicenaria A }\end{array}$ & 10.0 & 27.7 & 7.3 & 28.0 & 25.7 & 45.3 & $3 / 3(\mathrm{MR})$ & - & - \\
\hline $\begin{array}{l}\text { Cucumis sativus/Lagenaria } \\
\text { sicenaria B }\end{array}$ & 51.7 & 18.3 & 8.7 & 23.3 & 16.3 & 83.7 & $3 / 3(\mathrm{MR})$ & $\mathrm{HR}$ & 1.0 \\
\hline $\begin{array}{l}\text { Cucumis sativus/Lagenaria } \\
\text { sicenaria C }\end{array}$ & - & - & - & - & - & - & - & $\mathrm{HR}$ & 1.0 \\
\hline Lagenaria sicenaria & 168.3 & 45.7 & 8.3 & 41.3 & 38.0 & 197.9 & $3 / 3(\mathrm{MR})$ & - & - \\
\hline Lagenaria sicenaria & 103.3 & 39.3 & 20.3 & 38.3 & 26.0 & 161.9 & $3 / 3(\mathrm{MR})$ & MR & 32.7 \\
\hline Lagenaria sicenaria & - & - & - & - & - & - & - & $\mathrm{HR}$ & 1.0 \\
\hline $\begin{array}{l}\text { Cucumis sativus/cucurbita } \\
\text { maxima A }\end{array}$ & 12.3 & 1.7 & 1.7 & 1.7 & 1.3 & 15.7 & $1 / 1(\mathrm{HR})$ & - & - \\
\hline $\begin{array}{l}\text { Cucumis sativus/cucurbita } \\
\text { maxima B }\end{array}$ & 11.0 & 10.7 & 1.3 & 3.0 & 1.7 & 15.3 & $2 / 1(\mathrm{R})$ & $\mathrm{R}$ & 41.7 \\
\hline $\begin{array}{l}\text { Cucumis sativus/cucurbita } \\
\text { maxima C }\end{array}$ & - & - & - & - & - & - & - & $\mathrm{R}$ & 28.3 \\
\hline Cucurbita maxima & 59.7 & 4.3 & 1.7 & 3.3 & 3.0 & 64.7 & $1 / 1(\mathrm{HR})$ & - & - \\
\hline Cucurbita maxima & 82.0 & 42.0 & 35.0 & 101.7 & 98.3 & 218.7 & $4 / 4(S)$ & $\mathrm{HR}$ & 1.0 \\
\hline Cucurbita maxima $\mathrm{C}$ & - & - & - & - & - & - & - & $\mathrm{HR}$ & 1.0 \\
\hline $\begin{array}{l}\text { Cucumber, Cucumis sativus } \\
\text { var. Hesham A }\end{array}$ & 1365.3 & 54.0 & 13.3 & 50.0 & 45.7 & 1428.6 & $4 / 4(S)$ & - & - \\
\hline $\begin{array}{l}\text { Cucumber, Cucumis sativus } \\
\text { var. Hesham B }\end{array}$ & 1296.7 & 77.3 & 13.3 & 77.0 & 72.7 & 1387.0 & $4 / 4(S)$ & $\mathrm{HS}$ & 82.3 \\
\hline $\begin{array}{l}\text { Cucumber, Cucumis sativus } \\
\text { var. Hesham C }\end{array}$ & - & - & - & - & - & - & - & $\mathrm{s}$ & 58.3 \\
\hline New L.S.D 5\% & 45.6 & 21.0 & 11.5 & 34.7 & 34.7 & - & - & - & - \\
\hline New L.S.D 1\% & 62.2 & 28.6 & 15.8 & 47.4 & 47.4 & - & - & - & - \\
\hline
\end{tabular}

$\mathrm{A}=$ Nematodes Infected plants, $\mathrm{B}=$ Nematodes and fungi infected plants and $\mathrm{C}=$ Fusarium infected plants ,

- Letters in parenthesis are plant response to M. incognita infection according to Hemeng, (1989).

* GI/EI = galls and egg-masses index according to Taylor and Sasser 1978

${ }^{* *}$ In these column, The Values = Index , A = fungi infected plants

${ }^{* * *}$ Disease Symptoms Index according to Kesevan and Chounhury , (1977) ;

$0=$ Immune (I) ; (1) = Highly Resistant (HR) ; (2)=Resistant (R) ; (3) =Susceptible (S) ; (4) = Highly Susceptible (HS). 
Table 2. Different plant growth parameters of some cucurbit rootstocks infected by Meloidogyne incognita and/or Fusarium oxysporum in autumn season in pots under screen house conditions

\begin{tabular}{|c|c|c|c|c|}
\hline $\begin{array}{c}\text { Treatment } \\
\text { scion /grafted plant }\end{array}$ & $\begin{array}{c}\text { Shoot weight } \\
\text { (g) }\end{array}$ & $\begin{array}{c}\text { Shoot length } \\
(\mathrm{cm})\end{array}$ & $\begin{array}{c}\text { Root weight } \\
\text { (g) }\end{array}$ & $\begin{array}{c}\text { Root length } \\
(\mathrm{cm})\end{array}$ \\
\hline Cucumissativus/Lagenaria sicenaria A & 5.0 & 46.7 & 1.5 & 14.3 \\
\hline Cucumis sativus/Lagenaria sicenaria B & 9.5 & 52.3 & 5.4 & 23.7 \\
\hline Cucumis sativus/Lagenaria sicenaria C & 17.0 & 52.3 & 3.0 & 19.7 \\
\hline Lagenaria sicenaria A & 4.7 & 18.3 & 1.2 & 13.3 \\
\hline Lagenaria sicenaria B & 9.4 & 39.7 & 3.1 & 15.7 \\
\hline Lagenaria sicenaria C & 19.7 & 52.0 & 3.2 & 21.7 \\
\hline Cucumis sativus/cucurbita maxima A & 7.8 & 61.7 & 2.7 & 21.7 \\
\hline Cucumis sativus/cucurbita maxima B & 8.9 & 40.3 & 2.9 & 20.7 \\
\hline Cucumissativus/cucurbita maxima C & 13.9 & 52.7 & 4.5 & 36.0 \\
\hline Cucurbita maxima A & 13.7 & 27.3 & 4.6 & 29.3 \\
\hline Cucurbita maxima B & 7.8 & 30.0 & 2.1 & 15.0 \\
\hline Cucurbita maxima C & 12.3 & 44.7 & 4.3 & 30.7 \\
\hline Cucumber, Cucumis sativus var. Hesham A & 4.2 & 18.7 & 1.4 & 12.0 \\
\hline Cucumber, Cucumis sativus var. Hesham B & 3.4 & 17.4 & 1.3 & 12.3 \\
\hline Cucumber, Cucumis sativus var. Hesham C & 23.0 & 27.3 & 2.7 & 18.3 \\
\hline New L.S.D 5\% & 7.1 & 13.5 & 1.7 & 5.6 \\
\hline
\end{tabular}
$A=$ Nematodes Infected plants
$C=$ Fusarium infected plants

$B=$ Nematodes and fungi infected plants

cucumber(control) 
Table 3. Evaluation of grafted and non-grafted cucurbit rootstocks to infection by Meloidogyne incognita and /or Fusarium oxysporum on nematode population and Fusarium disease index in spring season in pots under screen house experiment.

\begin{tabular}{|c|c|c|c|c|c|c|c|c|c|}
\hline \multirow{3}{*}{$\begin{array}{c}\text { Treatment } \\
\text { scion/grafted plant }\end{array}$} & \multicolumn{5}{|c|}{ Number of Nematodes } & \multirow{3}{*}{ 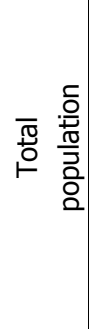 } & \multirow{3}{*}{ GI/EI* } & \multirow{2}{*}{\multicolumn{2}{|c|}{$\begin{array}{l}\text { Fusarium } \\
\text { Wilt }^{* *}\end{array}$}} \\
\hline & \multirow[b]{2}{*}{ 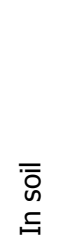 } & \multicolumn{4}{|c|}{ In roots } & & & & \\
\hline & & 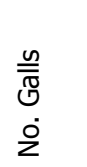 & 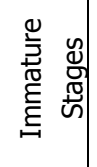 & 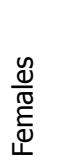 & 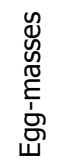 & & & 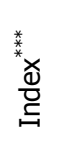 & 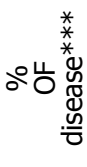 \\
\hline Cucumis sativus/Benincasa hispida (A) & 14.0 & 31.7 & 0.09 & 28.7 & 20.7 & 42.8 & $4 / 3(S)$ & $\mathrm{HR}$ & 1.0 \\
\hline Cucumis sativus/Benincasa hispida (B) & 57.0 & 18.7 & 0.14 & 32.7 & 28.3 & 89.8 & $3 / 3(\mathrm{MR})$ & $\mathrm{HR}$ & 1.0 \\
\hline Cucumis sativus/Benincasa hispida (C) & - & - & - & - & - & - & - & & - \\
\hline Benincasa hispida $(\mathrm{A})$ & 99.3 & 44.7 & 0.12 & 41.3 & 36.7 & 140.7 & $4 / 4(S)$ & $\mathrm{HR}$ & 1.0 \\
\hline Benincasa hispida (B) & 124.6 & 26.7 & 0.17 & 40.7 & 31.7 & 165.4 & $3 / 4(S)$ & $\mathrm{HR}$ & 1.0 \\
\hline Benincasa hispida (C ) & - & - & - & - & - & - & - & & - \\
\hline $\begin{array}{l}\text { Cucumis sativus/C.maximax } \\
\text { C.moschata (A) }\end{array}$ & 18.6 & 24.0 & 0.07 & 15.0 & 14.0 & 33.8 & $3 / 3(\mathrm{MR})$ & $\mathrm{HR}$ & 1.0 \\
\hline $\begin{array}{l}\text { Cucumis sativus/C.maxima x } \\
\text { C.moschata (B) }\end{array}$ & 16.6 & 21.0 & 0.07 & 17.0 & 15.3 & 33.7 & $3 / 3$ (MR) & $\mathrm{HR}$ & 1.0 \\
\hline $\begin{array}{l}\text { Cucumis sativus/C.maximax } \\
\text { C.moschata (C) }\end{array}$ & - & - & - & - & - & - & - & & - \\
\hline C.maxima x C.moschata (A) & 80.0 & 27.0 & 0.06 & 24.3 & 14.3 & 104.4 & $3 / 3(\mathrm{MR})$ & $\mathrm{HR}$ & 1.0 \\
\hline C.maxima x C.moschata (B) & 88.0 & 24.0 & 0.06 & 22.7 & 17.7 & 110.8 & $3 / 3$ (MR) & $\mathrm{HR}$ & 1.0 \\
\hline C.maxima x C.moschata (C) & - & - & - & - & - & - & - & & - \\
\hline Cucumis sativus var. Sinai (A) & $\begin{array}{c}1406 . \\
3 \\
\end{array}$ & 306.0 & 2.74 & 286.0 & 181.0 & 1590.0 & $5 / 5(H S)$ & MS & 35.0 \\
\hline Cucumis sativus var. Sinai (B) & $\begin{array}{c}1350 . \\
0\end{array}$ & 289.0 & 2.92 & 265.7 & 175.7 & 1618.6 & $5 / 5$ (HS) & MS & 35.0 \\
\hline Cucumis sativus var. Sinai (C) & - & - & - & - & - & - & - & - & - \\
\hline New L.S.D 5\% & 23,2 & 11.0 & - & 14.6 & - & - & - & & \\
\hline New L.S.D 1\% & 31.6 & 15.0 & - & 20.0 & - & - & - & & \\
\hline
\end{tabular}

$A=$ Nematodes Infected plants, $B=$ Nematodes and fungi infected plants and $C=$ Fusarium infected plants,

- Letters in parenthesis are plant response to M. incognita infection according to Hemeng, (1989).

* GI/EI = galls and egg-masses index according to Taylor and Sasser (1978)

** In these column, The Values = Index, $A=$ fungi infected plants

${ }^{* * *}$ Disease Symptoms Index according to Kesevan and Chounhury, (1977) are as follows:-

0 = Immune (I); (1) = Highly Resistant (HR) ; (2)=Resistant (R) ; (3) =Susceptible (S) ; (4) = Highly Susceptible (HS). 
Table 4. Different plant growth parameters of some cucurbit rootstocks infected by Meloidogyne incognita and /or Fusarium oxysporum in spring season in pots under screen house conditions

\begin{tabular}{|c|c|c|c|c|}
\hline $\begin{array}{c}\text { Treatment } \\
\text { scion /grafted plant }\end{array}$ & $\begin{array}{c}\text { Shoot } \\
\text { weight (g) }\end{array}$ & $\begin{array}{c}\text { Shoot length } \\
(\mathrm{cm})\end{array}$ & $\begin{array}{c}\text { Root weight } \\
\text { (g) }\end{array}$ & $\begin{array}{l}\text { Root } \\
\text { length } \\
(\mathrm{cm})\end{array}$ \\
\hline Cucumis sativus/ Benincasa hispida A & 27.7 & 67.8 & 13.7 & 15.7 \\
\hline Cucumis sativus/ Benincasa hispida B & 36.0 & 67.1 & 22.7 & 20.0 \\
\hline Cucumis sativus/ Benincasa hispida C & 34.7 & 15.0 & 15.7 & 6.7 \\
\hline Benincasa hispida A & 23.7 & 23.7 & 12.3 & 12.7 \\
\hline Benincasa hispida B & 33.3 & 43.0 & 12.0 & 19.0 \\
\hline Benincasa hispida C & 23.7 & 15.7 & 14.3 & 5.0 \\
\hline Cucumis sativus/ C.maxima XC.moschata A & 16.0 & 72.1 & 12.1 & 21.7 \\
\hline Cucumis sativus/C.maxima xC.moschata B & 32.0 & 70.7 & 13.0 & 25.0 \\
\hline Cucumis sativus/C.maxima $x$ C.moschata C & 26.7 & 17.7 & 27.0 & 9.3 \\
\hline C.maxima xC.moschata A & 12.8 & 20.5 & 9.3 & 20.7 \\
\hline C.maxima xC.moschata B & 24.7 & 37.0 & 9.3 & 19.0 \\
\hline C.maxima xC.moschata C & 20.3 & 10.7 & 18.3 & 6.3 \\
\hline Cucumis sativus var. Sinai A & 10.7 & 19.7 & 6.1 & 13.3 \\
\hline Cucumis sativus var. Sinai B & 11.3 & 24.7 & 7.7 & 17.0 \\
\hline Cucumis sativus var. Sinai C & 12.0 & 25.7 & 10.3 & 14.0 \\
\hline New L.S.D 5\% & 8.5 & 5.1 & 3.5 & 4.2 \\
\hline
\end{tabular}
$A=$ Nematodes Infected plants
$B=$ Fusarium infected plants
$C=$ Nematodes and fungi infected plants
cucumber(control) 
Table 5. Effects of grafted and non-grafted cucurbit rootstocks to infection by Meloidogyne incognita or/and Fusarium oxysporum on nematodes population and Fusarium disease indices in autumn seasons under screen house.

\begin{tabular}{|c|c|c|c|c|c|c|c|c|c|}
\hline \multirow{3}{*}{$\begin{array}{c}\text { Treatment } \\
\text { scion /grafted plant }\end{array}$} & \multicolumn{5}{|c|}{ Number of Nematodes } & \multirow{3}{*}{ 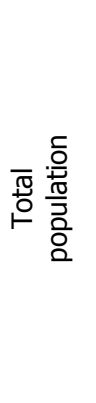 } & \multirow{3}{*}{$\begin{array}{c}\mathrm{GI} / \mathrm{EI} \\
*\end{array}$} & \multirow{2}{*}{\multicolumn{2}{|c|}{$\begin{array}{l}\text { Fusarium } \\
\text { Wilt }^{* *}\end{array}$}} \\
\hline & \multirow{2}{*}{$\begin{array}{l}\overline{\overline{0}} \\
\subseteq\end{array}$} & \multicolumn{4}{|c|}{ In roots } & & & & \\
\hline & & $\begin{array}{l}\frac{n}{\bar{N}} \\
\vdots \\
\dot{0}\end{array}$ & 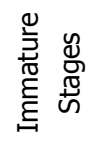 & 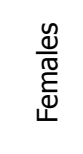 & 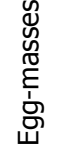 & & & 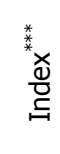 & 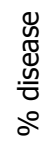 \\
\hline $\begin{array}{l}\text { Cucumis } \\
\text { sativus/Lageraria } \\
\text { sicenaria }\end{array}$ & 10.0 & 3.2 & 4.3 & 4.3 & 2.3 & 18.6 & $\begin{array}{l}2 / 1 \\
(\mathrm{R})\end{array}$ & $\mathrm{HR}$ & 1 \\
\hline Lagenaria siceraria & 168.3 & 22.6 & 15.1 & 13.0 & 10.8 & 196.4 & $\begin{array}{l}3 / 2 \\
(\mathrm{MR})\end{array}$ & $\mathrm{HR}$ & 1 \\
\hline $\begin{array}{l}\text { Cucumis } \\
\text { sativus/cucurbita } \\
\text { maxima }\end{array}$ & 12.3 & 2.7 & 3.3 & 3.4 & 2.0 & 19.0 & $\begin{array}{l}2 / 1 \\
(\mathrm{R})\end{array}$ & $H R$ & 1 \\
\hline Cucurbita maxima & 59.7 & 9.2 & 14.7 & 15.0 & 6.3 & 89.4 & $\begin{array}{l}2 / 2 \\
(R)\end{array}$ & $H R$ & 1 \\
\hline $\begin{array}{l}\text { Cucumber, Cucumis } \\
\text { sativus var. Hesham } \\
\text { (scion) }\end{array}$ & 1365.3 & 456.0 & 214.0 & 129.0 & 115.4 & 1708.3 & $\begin{array}{l}5 / 5 \\
(\mathrm{HS})\end{array}$ & $\mathrm{R}$ & 25 \\
\hline L.S.D 5\% & 45.6 & 0.49 & 0.55 & 0.52 & 0.47 & - & - & - & - \\
\hline
\end{tabular}

$A=$ Nematodes Infected plants, $B=$ Nematodes and fungi infected plants and $C=$ Fusarium infected plants ,

- Letters in parenthesis are plant response to M. incognita infection according to Hemeng, (1989).

* GI/EI = galls and egg-masses index according to Taylor and Sasser 1978

** In these column, The Values = Index , A = fungi infected plants

***Disease Symptoms Index according to Kesevan and Chounhury , (1977) are as follows:-

$0=$ Immune (I) ; (1) = Highly Resistant (HR) ; (2) =Resistant (R) ; (3) =Susceptible (S) ; (4) = Highly Susceptible (HS). 
Table 6. Effects of grafted and non-grafted cucurbit rootstocks to infection by Meloidogyne incognita or/and Fusarium oxysporum on nematodes population and Fusarium disease indices in spring seasons under Screen house.

\begin{tabular}{|c|c|c|c|c|c|c|c|c|c|}
\hline \multirow[b]{3}{*}{$\begin{array}{c}\text { Treatment } \\
\text { scion / grafted plant }\end{array}$} & \multicolumn{5}{|c|}{ Number of Nematodes } & \multirow{3}{*}{ 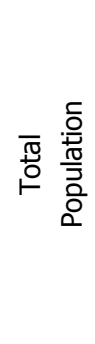 } & \multirow[b]{3}{*}{ GI/EI * } & \multirow{2}{*}{\multicolumn{2}{|c|}{ Fusarium Wilt ${ }^{* *}$}} \\
\hline & \multirow{2}{*}{ 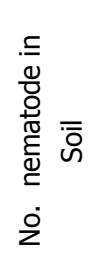 } & \multicolumn{4}{|c|}{ In roots } & & & & \\
\hline & & $\begin{array}{l}\frac{0}{\bar{N}} \\
\stackrel{\circlearrowleft}{0} \\
\dot{0}\end{array}$ & 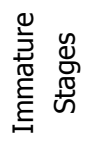 & 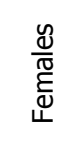 & 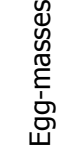 & & & $\underset{* * *}{\text { Index }}$ & $\begin{array}{c}\% \\
\text { diseas } \\
\text { e }\end{array}$ \\
\hline $\begin{array}{l}\text { Cucumis } \\
\text { sativus/ Benincasa } \\
\text { hispida }\end{array}$ & 14.0 & 9.6 & 2.5 & 3.7 & 2.4 & 20.2 & $\begin{array}{l}2 / 1 \\
(\mathrm{R})\end{array}$ & $H R$ & 1.0 \\
\hline Benincasa hispida & 99.3 & 2.5 & 1.7 & 3.7 & 1.7 & 104.7 & $\begin{array}{l}1 / 1 \\
(\mathrm{HR})\end{array}$ & HR & 1.0 \\
\hline $\begin{array}{l}\text { Cucumis } \\
\text { sativus/C.maximax } \\
\text { C.moschata }\end{array}$ & 18.6 & 1.0 & 1.0 & 2.0 & 1.0 & 21.6 & $\begin{array}{l}1 / 1 \\
(H R)\end{array}$ & HR & 1.0 \\
\hline $\begin{array}{l}\text { C.maximax } \\
\text { C.moschata }\end{array}$ & 80.0 & 10.6 & 2.0 & 2.0 & 1.0 & 84.0 & $\begin{array}{l}2 / 1 \\
(\mathrm{R})\end{array}$ & HR & 1.0 \\
\hline $\begin{array}{l}\text { Cucumis sativus } \\
\text { var. Sinai (scion) }\end{array}$ & 1406.3 & 115 & 135 & $\begin{array}{c}344 . \\
3\end{array}$ & $\begin{array}{c}274 . \\
3\end{array}$ & 1885.6 & $\begin{array}{l}5 / 5 \\
(\mathrm{HS})\end{array}$ & MS & 35.0 \\
\hline L.S.D $5 \%$ & 11.0 & 0.44 & 0.34 & 0.31 & 0.36 & - & - & - & - \\
\hline
\end{tabular}

$A=$ Nematodes Infected plants, $B=$ Nematodes and fungi infected plants and $C=$ Fusarium infected plants ,

- Letters in parenthesis are plant response to M. incognita infestaaccording to Hemeng, (1989).

* GI/EI = galls and egg-masses index according to Taylor and Sasser 1978

${ }^{* *}$ In these column, The Values = Index , $A=$ fungi infected plants

${ }^{* * *}$ Disease Symptoms Index according to Kesevan and Chounhury , (1977) are as follows:-

$0=$ Immune (I) ; (1) = Highly Resistant (HR) ; (2) =Resistant (R) ; (3) =Susceptible (S) ; (4) = Highly Susceptible (HS). 
Table 7. Shoot plant growth characteristics as affected by cucumber grafted onto different cucurbitaceous rootstocks in autumn season (20092010) under plastic house.

\begin{tabular}{|c|c|c|c|c|c|c|c|c|c|c|}
\hline \multirow[b]{2}{*}{$\begin{array}{c}\text { Treatments } \\
\text { Scion /grafted plant }\end{array}$} & \multicolumn{5}{|c|}{ Autumn 2009} & \multicolumn{5}{|c|}{ Autumn 2010} \\
\hline & Plant height $(\mathrm{cm})$ & $\begin{array}{c}\text { No. leaves / } \\
\text { plant }\end{array}$ & $\begin{array}{l}\text { Leaf area } \\
\left(\mathrm{cm}^{2}\right)\end{array}$ & $\begin{array}{c}\text { Chlorophyll } \\
\text { (spade) }\end{array}$ & $\begin{array}{c}\% \\
\text { Chlorophyll } \\
\text { Increment }\end{array}$ & $\begin{array}{l}\text { Plant height } \\
\quad(\mathrm{cm})\end{array}$ & $\begin{array}{c}\text { No. } \\
\text { leaves / } \\
\text { plant }\end{array}$ & $\begin{array}{c}\text { Leaf area } \\
\left(\mathrm{cm}^{2}\right)\end{array}$ & $\begin{array}{c}\text { Chlorophyll } \\
\text { (spade) }\end{array}$ & $\begin{array}{c}\% \\
\text { Chlorophyll } \\
\text { Increment }\end{array}$ \\
\hline Cucumber/L.sicenaria & 272.3 & 40.0 & 281.0 & 36.7 & 7.9 & 285.0 & 43.3 & 292.7 & 39.3 & 0.54 \\
\hline $\begin{array}{l}\text { Cucumber/Cucurbita } \\
\text { maxima }\end{array}$ & 282.7 & 42.0 & 286.0 & 39.4 & 15.9 & 302.0 & 45.0 & 300.0 & 40.3 & 0.80 \\
\hline $\begin{array}{l}\text { Cucumber, Cucumis sativus } \\
\text { var. Hesham (scion) }\end{array}$ & 219.3 & 33.0 & 205.3 & 34.0 & 0.0 & 271.0 & 34.7 & 207.3 & 37.3 & 0.0 \\
\hline L.S.D 5\% & 4.46 & 1.61 & 1.76 & 0.76 & & 2.49 & 1.88 & 0.94 & 1.2 & \\
\hline
\end{tabular}

Table 8. Cucumber yield as affected by cucumber grafted onto different cucurbitaceous rootstocks in autumn seasons (2009-2010) under plastic house:-

\begin{tabular}{|c|c|c|c|c|c|c|c|c|c|c|c|c|}
\hline \multirow[b]{2}{*}{$\begin{array}{c}\text { Treatments } \\
\text { Scion /grafted plant }\end{array}$} & \multicolumn{6}{|c|}{ Autumn 2009} & \multicolumn{6}{|c|}{ Autumn 2010} \\
\hline & $\begin{array}{l}\text { Time to } \\
\text { first } \\
\text { flower }\end{array}$ & $\begin{array}{l}\text { No. of } \\
\text { fruits }\end{array}$ & $\begin{array}{c}\text { Yield/ } \\
\text { plant } \\
(\mathrm{gr})\end{array}$ & $\begin{array}{c}\text { Total } \\
\text { yield/p } \\
\text { lant } \\
(\mathrm{Kg})\end{array}$ & $\begin{array}{c}\text { Total } \\
\text { yield/ } \\
\mathrm{m}^{2} \\
(\mathrm{Kg})\end{array}$ & $\begin{array}{c}\text { \% yield } \\
\text { increme } \\
\text { nts/m } \\
(\mathrm{Kg})\end{array}$ & $\begin{array}{l}\text { Time to } \\
\text { first } \\
\text { flower }\end{array}$ & $\begin{array}{l}\text { No. of } \\
\text { fruits }\end{array}$ & $\begin{array}{c}\text { Yield/ } \\
\text { plant } \\
(\mathrm{gr})\end{array}$ & $\begin{array}{c}\text { Total } \\
\text { yield/pla } \\
\text { nt (Kg) }\end{array}$ & $\begin{array}{c}\text { Total } \\
\text { yield/ } \\
\mathrm{m}^{2} \\
(\mathrm{Kg})\end{array}$ & $\begin{array}{l}\text { \% yield } \\
\text { increments } \\
/ \mathrm{m} \\
(\mathrm{Kg})\end{array}$ \\
\hline Cucumber/L.sicenaria & 30.3 & 61 & 620 & 2.13 & 4.69 & 24.1 & 25.7 & 57.3 & 720 & 2.10 & 4.77 & 39.6 \\
\hline Cucumber/Cucurbita maxima & 29.7 & 59 & 670 & 1.87 & 4.11 & 8.7 & 25.7 & 61.3 & 670 & 1.98 & 4.36 & 21.1 \\
\hline Cucumber, Cucumis sativus var. Hesham (scion) & 35.7 & 43 & 510 & 1.70 & 3.78 & 0.0 & 31.3 & 45.6 & 530 & 1.65 & 3.63 & 0.0 \\
\hline L.S.D.5\% & 1.15 & 1.15 & 0.01 & 0.06 & 0.03 & - & 0.03 & 0.09 & 0.01 & 1.63 & 1.15 & - \\
\hline
\end{tabular}


Table 9. Cucumber fruits characteristics as affected by cucumber scion grafted onto different cucurbitaceous rootstocks in autumn season (20092010) under plastic house.

\begin{tabular}{|c|c|c|c|c|c|c|}
\hline \multirow[b]{2}{*}{$\begin{array}{l}\text { Treatment } \\
\text { Scion /grafted plant }\end{array}$} & \multicolumn{3}{|c|}{ Autumn 2009} & \multicolumn{3}{|c|}{ Autumn 2010} \\
\hline & $\begin{array}{l}\text { Fruit length } \\
\mathrm{Cm}\end{array}$ & $\begin{array}{c}\text { Fruit } \\
\text { diameter } \\
\mathrm{cm} .\end{array}$ & $\begin{array}{c}\text { Fruit } \\
\text { weight } \\
\text { gr }\end{array}$ & $\begin{array}{l}\text { Fruit length } \\
\mathrm{cm}\end{array}$ & $\begin{array}{c}\text { Fruit } \\
\text { diameter } \\
\mathrm{cm} .\end{array}$ & $\begin{array}{c}\text { Fruit } \\
\text { weight } \\
\text { gr }\end{array}$ \\
\hline Cucumber/L.sicenaria & 15.7 & 3.0 & 120.0 & 15.0 & 3.5 & 127.0 \\
\hline Cucumber/Cucurbita maxima & 13.5 & 3.1 & 124.3 & 16.3 & 3.8 & 129.0 \\
\hline Cucumber, Cucumis sativus var. Hesham (scion) & 13.1 & 3.1 & 103.7 & 14.0 & 3.4 & 106.7 \\
\hline L.S.D.5\% & 1.89 & 0.27 & 1.49 & 0.58 & 0.19 & 1.51 \\
\hline
\end{tabular}

Table 10. Cucumber foliage macro- elements analysis as affected by grafted onto different cucurbitaceous rootstocks in autumn seasons (20092010) under plastic house.

\begin{tabular}{|c|c|c|c|c|c|c|c|c|c|c|}
\hline \multirow{2}{*}{$\begin{array}{l}\text { Treatments } \\
\text { Scion / grafted plant }\end{array}$} & \multicolumn{5}{|c|}{ Macro-elements (Autumn 2009) } & \multicolumn{5}{|c|}{ Macro-elements (Autumn 2010) } \\
\hline & $\mathrm{N}$ & $P$ & K & $\mathrm{Ca}$ & $\mathrm{Mg}$ & $\mathrm{N}$ & $P$ & K & $\mathrm{Ca}$ & $\mathrm{Mg}$ \\
\hline Cucumber/L.sicenaria & 2750 & 420 & 1816 & 420 & 93 & 2885 & 438 & 1889 & 509 & 89 \\
\hline Cucumber/Cucurbita maxima & 2040 & 290 & 1277 & 400 & 95 & 2388 & 338 & 1524 & 499 & 83 \\
\hline Cucumber, Cucumis sativus var. Hesham (scion) & 1657 & 245 & 1052 & 324 & 64 & 1714 & 259 & 1093 & 351 & 64 \\
\hline
\end{tabular}


Table 11. Shoot plant growth characteristics as affected by cucumber scion grafted onto different cucurbitaceous rootstocks in spring seasons (2010-2011) under plastic house.

\begin{tabular}{|c|c|c|c|c|c|c|c|c|c|c|}
\hline \multirow[b]{2}{*}{$\begin{array}{l}\text { Treatments } \\
\text { Scion /grafted plant }\end{array}$} & \multicolumn{5}{|c|}{ spring 2010} & \multicolumn{5}{|c|}{ spring 2011} \\
\hline & $\begin{array}{l}\text { Plant height } \\
(\mathrm{cm})\end{array}$ & $\begin{array}{c}\text { No. leaves / } \\
\text { plant }\end{array}$ & $\begin{array}{l}\text { Leaf area } \\
\left(\mathrm{cm}^{2}\right)\end{array}$ & $\begin{array}{c}\text { Chlorophyll } \\
\text { (spade) }\end{array}$ & $\begin{array}{c}\text { \% } \\
\text { Chlorophyll } \\
\text { Increment }\end{array}$ & $\begin{array}{c}\text { Plant } \\
\text { height } \\
(\mathrm{cm})\end{array}$ & $\begin{array}{l}\text { No. leaves } \\
\text { / plant }\end{array}$ & $\begin{array}{l}\text { Leaf area } \\
\qquad\left(\mathrm{cm}^{2}\right)\end{array}$ & $\begin{array}{c}\text { Chlorophyl } \\
\text { I }\end{array}$ & $\begin{array}{c}\text { \% Chlorophyll } \\
\text { Increment }\end{array}$ \\
\hline $\begin{array}{l}\text { Cucumis sativus/Benincasa } \\
\text { hispida }\end{array}$ & 283.7 & 45.0 & 395.0 & 42.5 & 4.8 & 295.0 & 50.7 & 375 & 41.0 & 16.1 \\
\hline $\begin{array}{l}\text { Cucumis sativus/C.maxima } \\
\text { x C.moschata }\end{array}$ & 271.0 & 40.0 & 376.3 & 38.3 & 1.6 & 275.0 & 47.3 & 352 & 36.0 & 2.0 \\
\hline $\begin{array}{l}\text { Cucumber, Cucumis sativus } \\
\text { var. Sinai (scion) }\end{array}$ & 225.7 & 34.6 & 327.0 & 37.7 & - & 235.7 & 33.3 & 310 & 35.3 & - \\
\hline L.S.D.5\% & 2.74 & 0.66 & 0.67 & 1.88 & & 1.33 & 1.15 & 0.67 & 0.66 & \\
\hline
\end{tabular}

Table 12. Cucumber yield as affected by cucumber grafted onto different cucurbitaceous rootstocks in spring seasons (2010-2011) under plastic house.

\begin{tabular}{|c|c|c|c|c|c|c|c|c|c|c|c|c|}
\hline \multirow[b]{2}{*}{$\begin{array}{c}\text { Treatments } \\
\text { Scion /grafted plant }\end{array}$} & \multicolumn{6}{|c|}{ Spring 2010} & \multicolumn{6}{|c|}{ Spring 2011} \\
\hline & $\begin{array}{l}\text { Time to } \\
\text { first } \\
\text { flower }\end{array}$ & $\begin{array}{l}\text { No } \\
\text { fruits }\end{array}$ & $\begin{array}{c}\text { Yield/ } \\
\text { plant } \\
(\mathrm{gr})\end{array}$ & $\begin{array}{c}\text { Total } \\
\text { yield/plant } \\
(\mathrm{Kg})\end{array}$ & $\begin{array}{c}\text { Total } \\
\text { yield/ } \\
\mathrm{m}^{2} \\
(\mathrm{Kg})\end{array}$ & $\begin{array}{c}\% \\
\text { yield } \\
\text { increm } \\
\text { ents/ } \\
\mathrm{m}^{2} \\
(\mathrm{Kg})\end{array}$ & $\begin{array}{l}\text { Time to } \\
\text { first } \\
\text { flower }\end{array}$ & $\begin{array}{l}\text { No } \\
\text { fruits }\end{array}$ & $\begin{array}{c}\text { Yield/ } \\
\text { plant } \\
(\mathrm{gr})\end{array}$ & $\begin{array}{c}\text { Total } \\
\text { yield/pla } \\
\text { nt (Kg) }\end{array}$ & $\begin{array}{c}\text { Total } \\
\text { yield/ } \mathrm{m}^{2} \\
(\mathrm{Kg})\end{array}$ & $\begin{array}{c}\% \text { yield } \\
\text { increme } \\
\text { nts } / \mathrm{m}^{2} \\
(\mathrm{Kg})\end{array}$ \\
\hline Cucumis sativus/ Benincasa hispida & 27.3 & 60.7 & 780 & 2.00 & 4.4 & 25.7 & 30.3 & 56.0 & 700 & 2.300 & 5.1 & 54.5 \\
\hline Cucumis sativus/C.maxima $\times$ C.moschata & 31.3 & 58.3 & 800 & 2.50 & 5.5 & 57.1 & 32.0 & 59.7 & 750 & 2.400 & 5.3 & 60.6 \\
\hline $\begin{array}{l}\text { Cucumber, Cucumis sativus var. Sinai } \\
\text { (scion) }\end{array}$ & 36.3 & 50.3 & 580 & 1,60 & 3.5 & - & 38.3 & 49.0 & 570 & 1.500 & 3.3 & - \\
\hline L.S.D.5\% & 1.15 & 0.94 & 0.01 & 5.11 & 0.03 & & 1.149 & 0.49 & 0.02 & 0.19 & 0.04 & \\
\hline
\end{tabular}


Table 13. Cucumber fruits characteristics as affected by cucumber grafted onto different cucurbitaceous rootstocks in spring season (2010-2011) under plastic house.

\begin{tabular}{|c|c|c|c|c|c|c|}
\hline \multirow[b]{2}{*}{$\begin{array}{l}\text { Treatment } \\
\text { Scion /grafted plant }\end{array}$} & \multicolumn{3}{|c|}{ Spring 2010} & \multicolumn{3}{|c|}{ Spring 2011} \\
\hline & $\begin{array}{l}\text { Fruit length } \\
\qquad \mathrm{cm}\end{array}$ & $\begin{array}{c}\text { Fruit } \\
\text { diameter } \\
\mathrm{cm} .\end{array}$ & $\begin{array}{c}\text { Fruit } \\
\text { weight } \\
\text { gm }\end{array}$ & $\begin{array}{c}\text { Fruit length } \\
\mathrm{cm}\end{array}$ & $\begin{array}{c}\text { Fruit } \\
\text { diameter } \\
\mathrm{cm} .\end{array}$ & $\begin{array}{c}\text { Fruit } \\
\text { weight } \\
\text { gm }\end{array}$ \\
\hline Cucumis sativus/ Benincasa hispida & 15.8 & 3.3 & 129.0 & 15.0 & 3.1 & 130.7 \\
\hline Cucumis sativus/C.maxima $\times$ C.moschata & 16.3 & 3.5 & 133.0 & 15.7 & 3.2 & 133.7 \\
\hline Cucumber, Cucumis sativus var. Sinai (scion) & 10.9 & 3.1 & 129.0 & 10.1 & 2.8 & 122.7 \\
\hline L.S.D.5\% & 1.89 & 0.27 & 1.49 & 0.58 & 0.19 & 1.51 \\
\hline
\end{tabular}

Table 14. Cucumber foliage macro- elements analysis as affected by grafted onto different cucurbitaceous rootstocks in spring (2010-2011) under plastic house.

\begin{tabular}{|c|c|c|c|c|c|c|c|c|c|c|}
\hline \multirow{2}{*}{$\begin{array}{l}\text { Treatments } \\
\text { Scion /grafted plant }\end{array}$} & \multicolumn{5}{|c|}{ Macro-elements (Spring 2010) } & \multicolumn{5}{|c|}{ Macro-elements (Spring 2011) } \\
\hline & $\mathrm{N}$ & $\mathrm{P}$ & $\mathrm{K}$ & $\mathrm{Ca}$ & $\mathrm{Mg}$ & $\mathrm{N}$ & $\mathrm{P}$ & $\mathrm{K}$ & $\mathrm{Ca}$ & $\mathrm{Mg}$ \\
\hline Cucumber/Benincasa hispida & 1589 & 351 & 1044 & 342 & 89 & 1583 & 358 & 1054 & 338 & 85 \\
\hline Cucumber/C.maxima x C.moschata & 1670 & 352 & 1032 & 336 & 83 & 1678 & 348 & 1028 & 342 & 87 \\
\hline Cucumber (scion) & 1666 & 340 & 1050 & 320 & 70 & 1660 & 349 & 1055 & 318 & 73 \\
\hline
\end{tabular}




\section{REFERENCES}

1. Amin, A.W., M. Abd-El Wanis, and Tomader G. Abdel Rahman. 2013. Evaluation of some cucurbitaceous rootstocks for resistance / susceptibility to root- knot nematode and Fusarium wilt under greenhouse conditions. Egypt.J.Agric.Res., 90 (4) :1561-1577.

2. Ashita, K. 1927. Grafting watermelon on squash. Japan. J. Hort. 39:5-8.

3. Anonymous. 2012. Economic and statistics, Ministry of Agriculture and land Reclamation Manual Report, Dept Agric, Egypt.

4. Cao, Z.P., Chen, G.K., Chen, Y.F., Yang, H., Han, L.F., and Katan, J. 2005. Comparative performance of nematode resistant rootstock and non-resistant tomato cultivars on soil biota. Allelopathy J., 15:85-94.

5. Charles, E. B., Zhao, X. and Hodges, A. W. (2012). Cost Benefit Analysis of Using Grafted Transplants for Root-knot Nematode Management in Organic Heirloom Tomato Production. HortTechnology, 22 (2): 252-257.

6. Davis, M. R. 2010. Grafting for Management of Southern Root-Knot Nematode, Meloidogyne incognita, in Watermelon. Plant disease., 94 (10):1195-1199.

7. Giannakou, I.O. and Karpouzas, D.G. 2003. Evaluation of chemical and integrated strategies as alternatives to methyl bromide for the control of rootknot nematodes in Greece. Pest Manag. Sci, 59: 883-892.

8. Hemeng, O. B. 1989. Screening cultivars/line of cowpea, HortScience Vigna unquiculate L. Walp for resistance to Meloidogyne incognita. Int. Nematol. Network Newsl., 6(1): 6-7.

9. Kacjan, M. N. and Osvald, J. 2004. The influence of grafting on yield of two tomato cultivars (Lycopersicon esculentum Mill.) Grown in a plastic house. Acta agriculturae Slovenica, 83: 243-249.

10. Kesevan, V. and Chounhury, B. 1977. screening for resistance to fusarium wilt tomato. Sabroa J., 9 (1): 57-65.

11. King, S. R. , Davis, A. R., Liu, W and Levi, A. 2008. Grafting for Disease Resistance. HortScience, 43(6): 1673-1676

12. Kobayashi, K. 2005. Vegetable grafting robot. Res. J. Food and Agric., 28:1520.

13. Kubota, C , McClure, M , Kokalis-B , Bausher, M. G. and Rosskop, N. 2008.Vegetable Grafting: History, Use, and Current Technology Status in North America. Hortscience, 43(6): 1664-1669. 
14. Lee, J.-M. 1994. Cultivation of grafted vegetables. 1. Current status, grafting methods, and benefits. 29:235-239.

15. Oda, M. (1994). New grafting methods for fruit bearing vegetables in Japan.Japan Agric, Res.Quart., 29: 187-194.

16. Oda, M. 1999. Grafting of vegetables to improve greenhouse production. Extension Bulitein food and fertilizer Technology Center. No.480, 11pp.

17. Oda, M. 2002. Grafting of vegetable crops. Sci. Rep. Agr. \& Biol. Sci. Osaka Pref. Univ., 54:49-72.

18. Plummer, D.T. 1971. An introduction to practical Biochem., Mc Graw Hill book Company (U.K.).Limited,124pp.

19. Sakata, Y., Ohara, T. and Sugiyama, M. 2008. The history of melon and cucumber grafting in Japan. Acta Hort. 767:217-228.

20. Sharma, G.C., K,B.Rastogi, Y.R.Shukla and M.L. Khan. 1995. Reaction of cucumber varieties to root knot nematode Meloidogyne incognita. Annals of Agri. Res., 16:33-35.

21. Sigüenza, C., Schochow, M., Turini, T. and Ploeg, A. 2005. Use of Cucumis metuliferus as a rootstock for melon to manage Meloidogyne incognita. J. Nematol., 37:276-280.

22. Taylor, A. L. and Sasser, J. N. 1978. Biology, Identification and control of rootknot nematodes, Meloidogyne species, Coop. Pub. Dept. Plant Pathol., North Carolina State Unive., and U.S. Agency, Int. Dev., Releigh NC., 111pp.

23. Tzortzakakis, E.A., Phillips, M.S. and Trudgill, D. L. 2000. Rotational management of Meloidogyne javanica in a small scale greenhouse trial in Crete, Greece. Nematropica, 30: 167-175.

24. Waller, W. and Duncan, G. (1969). Statistical Methods for Research Workers. Oliver and Boyd, London, 89pp.

25. Yi-Fei Liu, Hong-Yan Qi, Chun-Ming Bai, Ming-Fang Qi, Chuan-Qiang Xu, JingHong Hao, Yan Li and Tian-Lai, Li. 2011. Grafting Helps Improve Photosynthesis and Carbohydrate Metabolism in Leaves of Muskmelon. Int J. Biol Sci , 7(8):1161-1170. 


\section{تقييم بعض الأصول من نباتات الفصيلة القرعية}

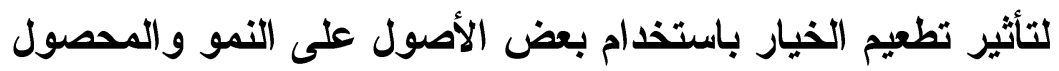

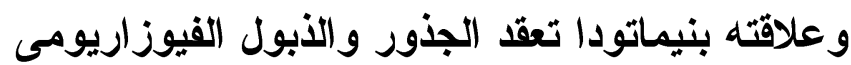

\section{منى عبد الونيي محمد 1 ، أمين وفدى أمين 2 ، تماضر جمعة عبد الرحمن 3}

$$
\begin{aligned}
& \text { 1- مركز البحوث الزراعية - معهُ بحوث البساتين- قسم الزراعة الدحمية . } \\
& \text { 2- قسم الحيوان والنيماتودا النزراعي - جامعة القاهرة - كلية النزراعة . }
\end{aligned}
$$

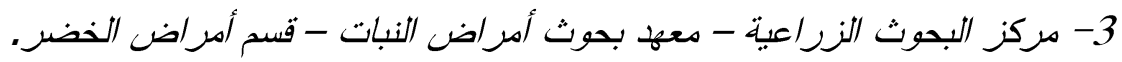

يعطى التطعيم على أصول مقاومة لبعض الإمر اض الكامنة بالتربة كالذبول الفيوزاريومى

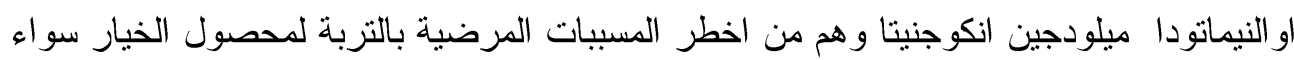

في الحقل الكشوف أو تحت الصوبات الزراعية ـ وتهدف الدراسة الحالية إلى انتخاب عدد أربعة أربعة أصول من الفصيلة القرعية بسبب مقاومتهم أو قابليتهم للإصابة بفطر الفيوزاريوم و النيماتودا في موسميين متتاليين 2010-2011 سو اء بالعدوى الصناعية في الأصص تحت ظروف الصوبات السلكية أو بالإصابة الطبيعية تحت ظروف الصوبات البلاستيكية وتأثير هذه الأصول على النمو فئن و المحصول - ومن هذه الأصول اليقين Lagenaria sicenaria و الكوسة الثنتوية Cucrbita maxima في الموسم الخريفي و wax melon وهجين الايروكولى C. maxim × C. moshata في الموسم

الربيعي و استخدم هجين هشام وهجين سيناء كطعم في الموسم الخريفي و الربيعي على التو الي .

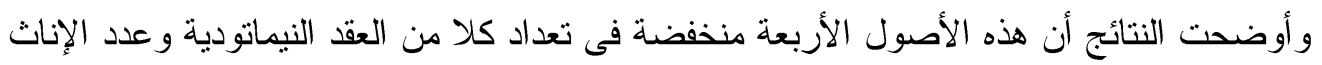

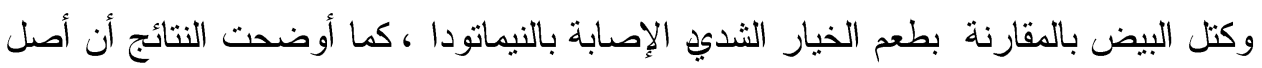

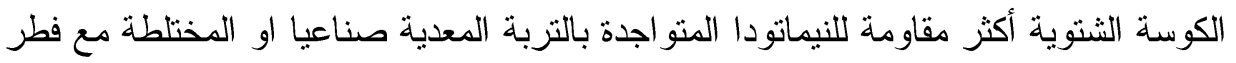

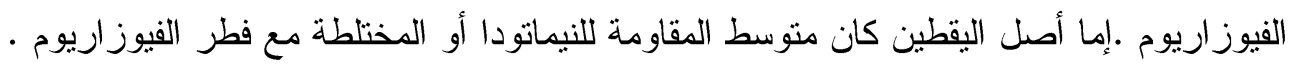

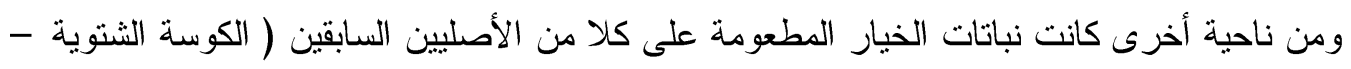
اليقطين ) ومعدية بالأصص أكثر مقاومة سو اء المعدية بالنيماتودا فقط او المختلطة بالفطر وبالنسبة التبن

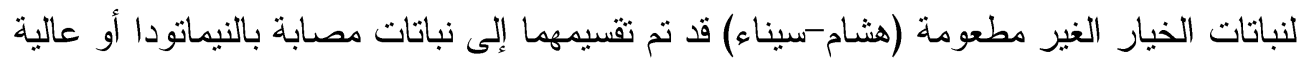

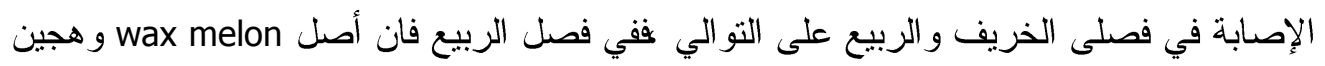

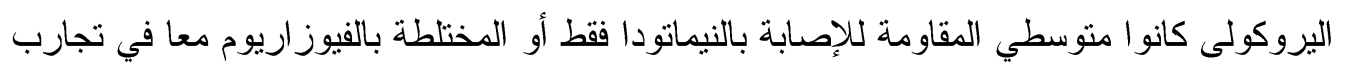
الأصص أما فصل الخريف وجد إن النباتات المطعومة و الغير مطعومة نم تدريجها كنباتات مقاومة بلونة

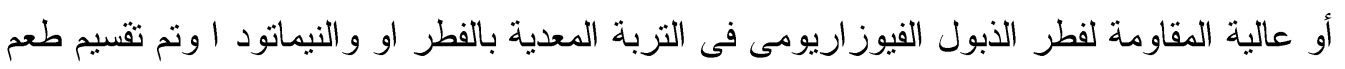

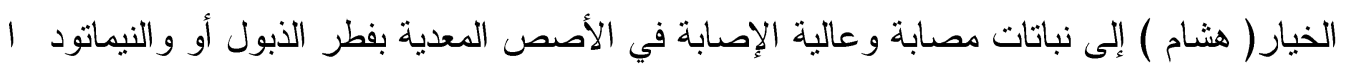
على التو الي • و أيضا في فصل الربيع كانت كل النباتات المطعومة وغير المطعومة عالية المقاومة الإنة 
لفطر الفيوز اريوم بالمقارنة بطعم الخيار ( سيناء) الذي تم تقسيمه كنبات عالي الإصابة في الأصص في كل الحالات التي تم عدواها بفطر الذبول و النيماتودا ـ وقد أثنارت النتائج إلى أن كلا المسببين

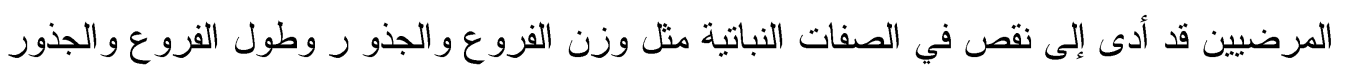
عندما تم عدو اها بالنيماتودا أو الفطر بالمقارنة بالنباتات الغير معدية كما أن العدوى بالنيماتودات التهات

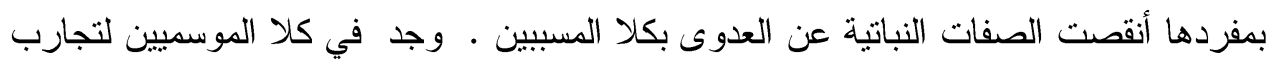

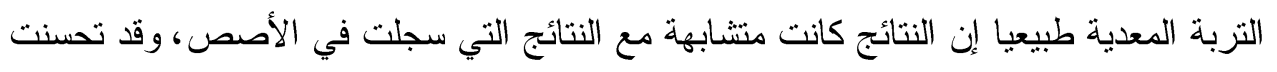
الصفات النباتية و إنتاجية الخيار (عدد الثمارو الانتاج الكلى لكل نبات و الإنتاجية لكل متر مربع) وصفات الثمار ومحتوى الكلوروفيل في أوراق النبات بالمقارنة بطعم الخيار ( هشام - سيناء)الغير

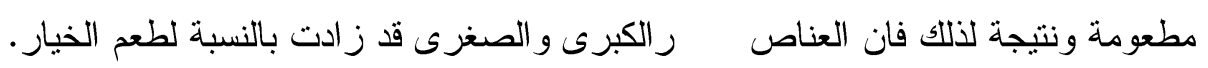

